\title{
The Science Integrationof Ulu al-albab Perspective (Campus Development towards World Class University)
}

\author{
Muhammad Fahim Tharaba ${ }^{1}$, Zulfi Mubaroq ${ }^{2}$, Ali Nasith ${ }^{3}$, Bambang Sugiyono Agus Purwono $^{4}$ \\ ${ }^{1,2,3}$ Universitas Islam Negeri Maulana Malik Ibrahim, Malang, Indonesia \\ ${ }^{4}$ State Polytechnic of Malang, Malang 65141, Indonesia \\ fahimtarbiyah@yahoo.com, bambangsap2015@gmail.com
}

\begin{abstract}
In this era of industry 4.0 or disruptionwhich becomes global, wherethe effect of technology especially information and communication and transportation runs rapidly, it is very difficult to find Ulu al-albabprofile that really can be standard in the alQur'an because Ulu al-albabis not only intellectual, but also emotional spiritual ability. The focus of this research is to find out the model of the science integration that is developed at the State Islamic University of Maulana Malik Ibrahim (UIN) Malang. This research method is qualitative approach. The results of the research are: (1) The philosophy of the science integration of ulu alalbab perspective developed by the UIN Malang is understood that the term integration is actually the same as the term of spirituality of spirituality that is also the term Islamization, that the keywords of the concept of integration of science are all true knowledge originating from God (Allah/al-Haq), with the ulul albab method that produces: (a) Morals, (b) Spiritual, (c) Science, and (d) Professionalism; (2) The model of the science integration of ulu al-albab perspective developed by the UIN Malang should be directed in order to ground the concept of ulul albab which is associated with mind, heart, intellect, insight, understanding, wisdom, with strategy, namely: (a) Increasing integration; (b) Sharpening sensitivity; (c) Ensuring relevance; (d) Developing; and (e) Maintaining independence.
\end{abstract}

Keywords

campus development, science integration, ulu al-albab

Article Received: 10 August 2020, Revised: 25 October 2020, Accepted: 18 November 2020

\section{Introduction}

Science is always getting developed rapidly.So is the human thought which is always developing from the mythic stage to the supra rational thinking. It is the same as Peursen's term "from the mythic stage, ontological stage, to the functional stage [1].

Religion and Science are the uniting entities (integral) which cannot be separated one from the other. Therefore, every discourse about methodology needs a touch of philosophy. Without the sense of philosophy, a methodology will miss its substance. Epistemological vision is needed which can spell out integrally and integratedly the three main currents of Islamic thought, namelytrust, sharia, and moral (aqidah, syari'ah, and akhlaq). The tendency to enforce the moral value dogmatically to the scientific argumentation will only set back the science to the period of pre-copernicus and it will invite the possibility of occurring The Galileo-style inquisition (1564-1642 AD) in this modern era. That is the tendency to ignore the moral value in developing science and technology will not also make it be humanism. This case becomes the foundation of integralism paradigm and secularisation paradigm isthat are needed for science [2]. If moslem does not want to be left behind by the western, it is time to revive Islamic intellectual heritage which has been neglected or redefine the knowledge using epistemology as the basic which derived from the revelation (read: alQur'an dan al-Hadis). As what Anees [2] stated that: "Education innovations in Islamic world this time is spurredto build western intellectual pole of imitations than to reshape their source of mind. If we do not redefine Islamic world-view concept, we will only incised wound of our past intellectuality." Alparslan Acikgenc [3] stated that "Developed four Islamic world views as the structure of the comprehensive islamic study: (1) faith (îmân) as the world structure; (2) science (al'ilm) as the knowledge structure; (3) Islamic Jurisprudence (fiqh or alfiqh) as the value structure; (4) caliphate (khalîfah)as the human structure.'

Osman Bakar [4] stated that:"to build Islamic knowledge structure we must develop four components which he called the theoretical structure of science." Those four are: (1) subject 
and object of knowledge material which build the knowledge body in a concept, facts or data, theories, and laws, and its logical relation; (2) premises and basic assumptions which become basic of science epistemology; (3) the methods of science development; and (4) the purpose to be reached by the science."

Wan Ramli [5] stated that: "supported the idea to get Arabic language back, as the language of alQuran to its original and true position as the science language of the entire Islam world and afford to unite moslem scientist to the direction to move forward moslem society in the field of science and technology."

Stenberg [6,7] stated that: "Maurice Bucaille became interested in Islam, as he learned Arabic and studied the Qur'an in its original language."

On the other hand, al-Qur'an placed them (ulualalbab) in the special position, as those who are able to think while others are not able to. In this era of industry 4.0 or disruption which becomes global, where the effect of technology especially information and communication and transportation runs rapidly, it is very difficult to find Ulu al-albabprofile that really can become standard in the al- Qur'an because Ulu alalbab(meaning a good mannered person in worshipping Allah) is not only intellectual, but also they have to have emotional spiritual ability [8].

Mat Rofa [9] stated that: "emphasized the knowledge classification based on Islamic epistemology is cognitive knowledge that is classified into three main categories: metaphysics, mathematics, and natural science. Classification in the Islamic epistemology generally is explained by the term of intellectual science (al-'ulum al'aqliyyah) or transmitted science (al-'ulum alnaqliyyah). Transmitted science only comes from al-Qur'an. Mathematics and natural science is classified under the intellectual knowledge. In term of intellectual sciences, metaphysics is the last destination of all the branch of the science. In this schema, technology is called as the technical output of the basic natural science." Nevertheless, knowledge which is gotten from the view of the western world is different from the one which comes from the view of Islam world. Furthermore, Mat Rofa [9] stated that: "The great difference of principle of the Islam and western can be seen from the general principle of causality - every cause must have consequence - which is disputed by al-Ghazali who argued that the relation of them both is not needed but it is only a habit."

Mat Rofa Mat Rofa [9] stated that: "Descartes believed in causality principle: Although in the mechanical point of view, God plays his role in the making of the heaven and the earth in first six days, yet cosmos behaved the same way as an automatic machine on his way without God's disruption. Galaxies character which rotates in the macro world will be compared with the micro world, the atom structure which rotates in the same way, the same orientation and proportional order. This is not only part of what is called natural law but that is the interpretation of the simple Rofa, that is part of Allah's law. This showed the presence of the God who is the only One, the Creator of the universe, small and big creatures, the macro and micro of the world. The uniform law which manages the earth and the heaven showed the presence of the unique Creator, Allah almighty."

In the end, Mat Rofa [9] concluded that:"in the light of the positivism developed in the western paradigm, the metaphysical realm, knowledge is entirely eliminated so it reduced modern ethical domain and science and it becomes free value. So that, Islam paradigm is needed to be model of integrated development of the society, namely: physics and spiritual. In the case of higher education, because mostly the books which are taught are written in the western paradigm, so the writing of the new texts as the need to filter reformation is important." Therefore, study by the theme "The Science Integration: Ulu al-albab Perspective (Campus Development Towards World Class University)" is important.

\section{RESEARCH METHOD}

This research needs the deep observation in the natural setting which is known as qualitative approach $[10,11]$ as stated as: "naturalistic approach in education field. The steps of this research are firstly, data collection of the site of the research (UIN Malang) as the subject. The data entered are observed, coded and made by seeing the categories developed in a theme, so it will become tentative conceptual result about the model of the science integration developed in site of the research. Secondly, based on the conceptual result of the subject, it made the analysis by making conceptual development which was 
resulted by the subject. By these steps, the steady conceptual result can be obtained and can be abstracted deeply about the model of the science integration developed in the site of the research. To reveal the last result, modified analytic induction is applied as the way to develop and verify the theory."

\section{RESULTS AND DISCUSSIONS}

Ulu al-albab's perspective of science integration model developed by the UIN Malang in grounding the concept of ulul albab begins with the meaning of Ulul albab. Ulul albab is a language derived from two words: "ulu and al-albab. Ulu means who has, while al-albab has various meanings. The word ulul albab appears sixteen (16) times in the al Qur'an. In the Indonesian translation, the most commonly used meaning is "akal" (mind). Therefore, "ulul albab is often interpreted as "having a mind" or "a person who has mind." $A l$ $a l b a b$ is plural and comes from al-lubb. This plural form indicates that ulul albab is a person who has multiple layers of brain, or a sharp brain."

A research of the English translation finds more diverse meanings. "Ulul albab has several meanings, which are linked to the mind, heart, intellect, insight, understanding, and wisdom."

The interpretating of various interpretations of verses containing the word "ulul albab" results in a big conclusion: ulul albab decorates its time with two main activities, namely thinking and remembrance. Both of these activities go hand in hand.

As a concept, ulul albab needs to be operationalized or familiarized. The following strategies are imagined after doing exegesis of the Qur'an (tadabbur)on various verses above, namely: (a) increasing integration, (b) honing sensitivity, (c) ensuring relevance, (d) developing imagination, and (e) maintaining independence.

Figure 1 shows the Roadmap of UIN Malang to become the World Class University (WCU). Fabienne Lind [12] stated that: "Steps for multilingual Dictionary Construction; The first obvious task for the construction of a multilingual dictionary is defining the target concept. After specifying what the dictionary should actually measure, the subsequent steps include: the preselection of dictionary keywords, their translation (if necessary) and evaluation, and, finally, the assessment of the overall dictionary performance. All these steps are performed in an iterative manner until the overall dictionary performance assessment yields satisfactory results."

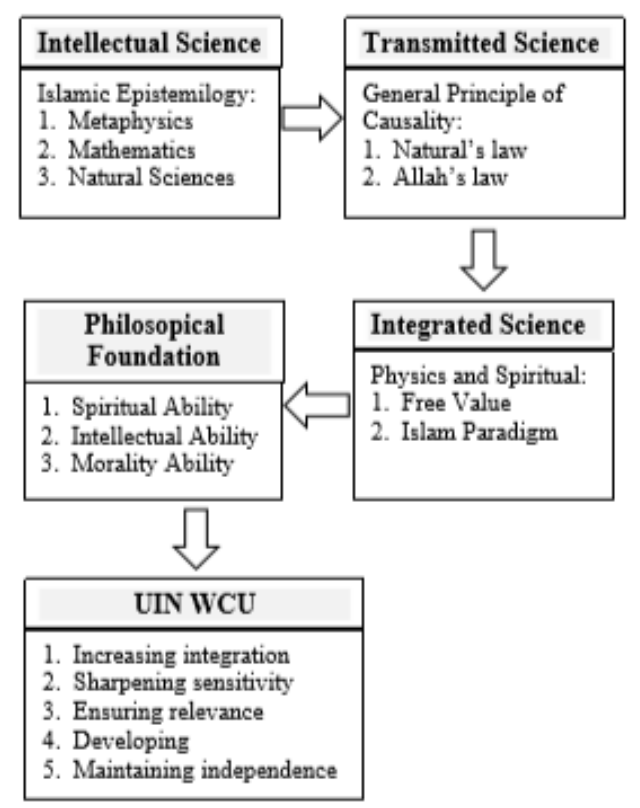

Source: [12].

Figure 1. Roadmap of UIN Malang World Class University

Figure 2 shows Fishbone Diagram of UIN WCU. Renee Clary [16] stated that: "Fishbone diagrams, also known as Ishikawa (Kaoru Ishikawa, a professor in Tokyo University, Japan) or Causeand-Effect diagrams. In the fishbone diagram, the head of the fish represents the summative effect or outcome of the information presented in the fish skeleton. Each of the fish's ribs represents a cause that contributes to the final effect."

Jung Tsun Liu [17] stated that: "TQM implementation can effectively enhance their performance on education and training."

\section{The Philosophy of The Science Integration of Ulu Al-Albab Perspective}

Muhammad Fahim Tharaba [13] stated that: "The philosophy of integration of perspective Ulu alalbab science developed by the UIN Malang was originated from God,embodied in the verses of Qur'aniyah (qauliyah), and nature (kauniyah)verses by observation result (experiment, and logical thinking), with a philosophical foundation, namely: ontology (spiritual ability), epistemology (intellectual ability), and axiology (morality ability) to create new knowledge which is in accordance with their fields, with the characteristics of ulul albab, such 
as pray (dzikir)robustness of semipermeable (aqidah), intellectual thought/brilliance (intersubjective testability), good deeds/working positively (creative imagination) based on good manner (akhlakul karimah) (objective cum subjective and subjective cum objective) with the process of recite (tilawah, tazkiyah, ta'lim, andhikmah), produce integrative science with synergistic integration strategies, namely (1) mastery of science and technology, (2) Islamic sciences, and (3) Islamic personality, which is packaged flexibly using link and match, which ultimately results in professional intellectual scholars/professional intellectual intellect.

Sayyed Hosen Nasr [14] stated that "The integration is a way of thinking.Unfortunately in modern way; other than humans are seen as objects. The position of subjects and objects, there are interrelations of subjects and objects, modern science uproots it. Sayyed Hosen Nasr reviewed the science in search of God. So that the term "science sorrow" appears; empiricist perspective. Revelation departs from the Prophet. Therefore, modern science is needed.

"Religion" and "science" are entities that are united (integral) inseparable from one another. So that each discourse on methodology requires philosophical touches, without a sense of philosophy, a methodology will lose its substance, epistemological vision is needed that can describe integrally and integrated towards the three main currents in Islamic teachings, i.e. trust, sharia, and moral (aqidah, syari'ah, and akhlaq). The tendency to enforce the moral value dogmatically to the scientific argumentation will only set back the science to the period of pre-copernicus and it will invite the possibility of occurring The Galileo-style inquisition (1564-1642 AD) in this modern era. So as the tendency to ignore the moral value in developing science and technology will not also make it be humanism." This is where the need for the paradigm of integralism and desecularization of science [1]

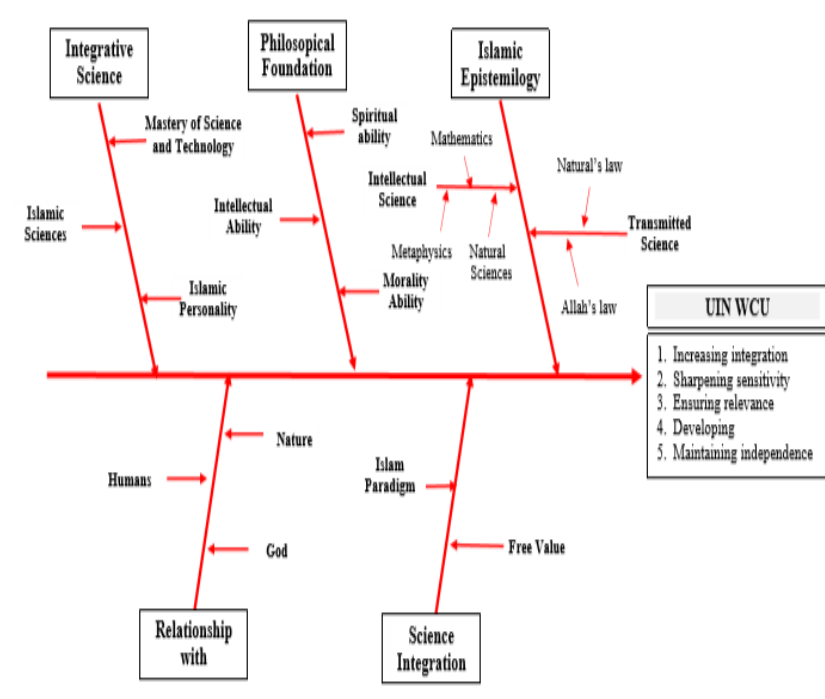

Source: [15], [16].

Figure 2. Fishbone Diagram of UIN WCU

Furthermore, Zainuddin [1] explained related to the philosophy of integration of Ulu al-albab's perspective of science developed by UIN Malang that in Islamic content, there are 3 relations, namely: a) Relationship with God; b) Relationship with humans, and c) Relationship with nature. The integration of Islam and science is inherently inherent in Islam. The cause of integration arises, because of secularization, so that integration is actually only revitalization and development. As for philosophically integration, still at the process level, attaches verses to existing knowledge. It is hoped that a scientific revolution will occur, with the Qur'an coming up with objective paradigms or theories, scientific theories that are built from the Qur'an."

Khozin's [18] opinion that reinforces expressed that:"The philosophical basis and methodology for the development of integrative science at the UIN Malang departed from four things, namely: a) Paralleling religion with philosophy, that religion and philosophy are normative; and presenting a worldview, b) Islamic Universalism, that Islam is a prerequisite to the concept of distant science; and unlimited sky as wide as the universe, c) The alignment of the concept of science with Islam, that the meeting point of both functions: religion as a way of salvation; and science as a path to prosperity, and d) Point vortex theory, that the Qur'an and hadith are a vortex of all science, as well as a foundation for ontology, epistemology and axiology of science, which originated from Allah (al-Haqq), that (1) There is no conflict 
between empirical truth and revelation, (2) There is no conflict between reason and revelation, and (3) Every study of natural law, patterns and parts are temporary, which are dialogical in the context of producing natural sciences, social sciences and humanities with the ulul albab methodology which produces: 1). Morals, 2) Spiritual, 3) Science, and 4) Professionalism."

Muhammad Cholil Nafis [19] stated that: "Integration can be done in universities. Scientific integration in the context of Islamic Higher Education can be done by opening study programs or scientific majors that integrate religious and general science. To achieve the epistemological integration level of religious and general science, integration must be carried out at the level of ontological integration, integration of science classification and methodological integration. Currently it is in the process of Islamization as well as the integration of science, such as Islamic politics, Islamic medicine, Islamic art, Islamic psychology, and Islamic economics, and so on."

For this reason, in order to understand the values of revelation, Muslims must utilize science. Without knowledge in the effort to understand revelation, Muslims will continue to be left behind by other people [20]. The reality now is that science plays a crucial role in determining the level of progress of humanity.

Besides the problem of backwardness in science, there is the greatest thing that is faced by Muslims today is related to the paradigm of thinking. Muslims still think absurdly (run away). For example, in understanding the Qur'an, Muslims are still searching for the mystical side of certain epistles rather than developing discourses on faith, humanity and knowledge. Whereas al-Qur'an is full of values of faith, humanity, civilization and science.

The Islamic sciences and personality are two aspects that support each other; and together become a foundation for the development of science and technology. It can be concluded, the integration of science means the mastery of science and technology combined with Islamic sciences and the Islamic personality [21].

Furthermore, Turmudi [21] commented that "Synergistic integration between religion and science will consistently produce reliable resources in applying knowledge possessed by being strengthened by strong spirituality in facing life."Islam is no longer considered an old- fashioned religion, but rather a need to actualize oneself in various fields of life, and as a facility for the development of science and technology. Imam Munandar [9] stated that: "The concept of integralism of science is a unification paradigm for natural and religious sciences, not only uniting these sciences but also becoming a paradigm of social and human sciences. Islam is not only a point of view or a complement but is the guardian of every act or work of science."

Yahya and Fauzan [5]stated that: "The concept of scientific integration also departs from the doctrine of the oneness of Allah (tawhîd)," as stated by Seyyed Hossein Nasr [14], "The arts and sciences in Islam are based on the idea of unity, which is the heart of the Muslim revelation." The doctrine of the oneness of God, or faith in the view of Isma'il Razi al Faruqi, "is not merely an ethical category, but it is a cognitive category related to knowledge, to the truth of its propositions. Because the nature of the content of his proposition is the same as the nature of the first principles of logic and knowledge, metaphysics, ethics, and aesthetics, then by itself in the subject he acts as a light that illuminates everything."Al-Faruqi [5] stated that: "As principle of knowledge, al tawhîd is the recognition that Allah, the $\operatorname{Truth}($ al-Haqq $)$ is, and that $\mathrm{He}$ is One. This implies that all contention, all doubt, is referable to Him; that no claim is beyond testing, beyond decisive judgment. Al-tawhîd is the recognition that the truth is indeed knowable, that man is capable of reaching it. Skepticism which denies the truth is the opposite of unification or oneness of God (al tawhid). It arises out of a failure of nerve to push the inquiry into truth to its end; the premature giving up of the possibility of knowing the truth." For al-Faruqi, acknowledging the Godhead of God, and alFaruqi's views reinforce the assumption that a single source of truth means that it is impossible to have two or more sources of ignorance. This is at the same time proof that scientific integration is compatible with the principle of al-tawhîd. To say that "the Truth is one, therefore is not only the same as asserting that God is one, but also the same as asserting that there is no other god but God, which is a combination of the disclaimer and affirmation stated by an Islamic creed (syahadah)." [5]. For this reason, we need to integrate these sciences because there is really no 
difference between general science and religious science.

In a philosophical view, the integration of religion and general science has a very solid foundation, because such integration can be found in the philosophical thinking of the past, "al-Ghazali and Ibn Khaldun used the concept of an integral and holistic science in the foundation of monotheism (tawhid) according to Ismail al-Faruqi as the essence of Islamic civilization which unifies all the diversity whatever Islam has received from outside. Their dichotomy is just a kind of not a separation, let alone a rejection of the validity of one another as a discipline. As a result in classical Islamic times there was no dualism [22]." Thus the notion of the integration of science that we must understand and then be developed in looking at the era of globalization. This is the moral responsibility of scientists in order to save the nation's civilization and even the world.

From there it can be concluded, the philosophy of science integration of Ulu al-albab's perspective developed by the State Islamic University of Maulana Malik Ibrahim Malang is understood that the term integration is actually the same as the term of spirituality and also the term Islamization, from various studies, opinions and research results. The key concept of the integration of knowledge is that all true knowledge comes from Allah (al-Haq). Science is how to describe Allah $(a l-H a q)$. The integration of Islam and science is inherent, which is further elaborated in an integrative scientific building structure, which is a combination of studies originating from the verses of qauliyah (al-Quran and al-hadith), and kauniyah verses (the results of observations, experiments and reasoning logical), so that the most popular division for understanding science is division into the fields of ontology, epistemology, and axiology. The integration of science in the context of Islamic higher education can be done by opening study programs or scientific majors that integrate religious and general sciences, to achieve epistemological integration of religious and general sciences, must be done at the level of ontological integration, integration of science classification and methodological integration, with mastery of science and technology combined with Islamic sciences and Islamic personality with read (Iqro')sourced from the Qur'an and dialogic in order to produce natural sciences, social sciences and humanities (al-Kawn).

\subsection{The Model of The Science Integration of Ulu al-albab's PerspectiveDeveloped by The UIN Malang}

Ulu al-albab's perspective of science integration models developed by the UIN Malang begins by referring to the opinion of Husni Thoyyar [5], who explained that: "The systematic integration models of science is not easy. There are:

1. Increase integration. "Ulul albab maintains the integration between thinking and dhikr, between science and faith. The integration of aspects of remembrance and thought of ulul $a l b a b$ is intended to be implemented into three levels of Islamization: (a) Self-Islamization, aimed at becoming a pious human being, including socially pious; (b) Islamization of institutions, by injecting values into decision making and business process design; and (c) "Islamization" of science, which is now more commonly referred to as the integration of science with Islamic values."

2. Sharpening sensitivity. "Thinking requires sensitivity [23]. The same phenomenon can provide a variety of meanings if approached with different levels of sensitivity. Sensitivity can be sharpened by looping, which is in line with the Surah Al-Alaq verses 1-5, that critical reading is repeated (in verses 1 and 3). This reading is still accompanied by remembrance: based on 'the name of Allah' (verse 1) and by still 'glorifying God' (verse 3) '.

3. Ensuring relevance. "The thought process must produce benefits. Here, the issue of relevance becomes important. It could be that the ability of human thinking has not been able to open the veil and understand it well, aka functional thinking. But for ulul $a l b a b$, everything is returned to the belief that Allah created everything with a purpose, not in vain [23]."

History records that science continues to develop. What is written in the al Qur'an is not all that can be understood easily in the coming down. For example, modern science has found that the sun shines (dliya'an) and the moon shines (nuuran). 
Layman's understanding previously assumed that the moon was shining. The moon does not shine but shines because it reflects light from the sun. Chlorophyll, or leaf green substancewas only discovered by modern knowledge long after this verse came down [23].

4. Developing imagination. "The combination of activity of thought and remembrance should produce the imagination of more advanced people and Muslims [23]. To move and move forward, we need to have an imagination of the future and not be caught up in a reactive attitude that consumes energy. Therefore, ulul albab must use critical, creative, and contemplative thoughts to test, reflect, question, authorize, criticize, and imagine. The critical character of the character of remembrance arises when dealing with concrete problems. Remembrance means remembering or getting a warning. Therefore, the character of the person who remembers is reminding. Here, it can be added that the object of thinking also includes social phenomena connected with various stories of the apostles also emphasizes the importance of this critical aspect because one of the tasks of the apostle is to give warnings [23]."

5. Maintaining independence. "Ulul albab should also be accustomed to thinking independently. Not based on current interests and current context. The basis for thinking is perennial or eternal values. We are asked to be independent in opinion, only accountability will be asked for what he did, and asked to be careful in assessing [23]. This independence becomes very important in the posttruth era when emotions are more prominent than common sense. Here, independence in thinking becomes a filter of public narratives which is often difficult to verify.

\section{CONCLUSIONS}

The philosophy of the science integration of ulu al-albab perspective developed by the UIN Malang is understood that the term integration is actually the same as the term of spirituality and also the term Islamization, that the keywords of the concept of integration of science are all true knowledge originating from Allah (al - Haq), so science is how to describe Allah (al-Haq). The integration of Islam and science is inherently, which is further elaborated in an integrative scientific building structure, which is a combination of studies originating from the verses of qauliyah (al-Quran and al-hadith), and kauniyah verses (the results of observations, experiments and logical thinking), so that the division to understand science is a division into the field of ontology, epistemology, and axiology, with the mastery of science and technology combined with Islamic sciences and Islamic personality with the means of Iqro'sourced from the Qur'an and al- Kawn, who is dialogical in order to create natural sciences, social sciences and humanities with the ulul albab methodology that produces: (a). Morals, (b) Spiritual, (c) Science, and (d) Professionalism.

The model of the science integration of ulu alalbab perspective developed by the UIN Malang should be directed in order to ground the concept of ulul albab which is associated with mind, heart, intellect, insight, understanding, wisdom, with strategy, namely: (a) Increasing integration; (b) Sharpening sensitivity; (c) Ensuring relevance; (d) Developing; and (e) Maintaining independence. So that the integration model of ulu al-albab's perspective of science developed by UIN Malang is a model of integration of higher education institutions which is elaborated in an integrative scientific building structure, with the metaphor of the tree of knowledge.

\section{References}

[1] Zainuddin, Muhammad. 2013.Towards the science and religion integration, Tuesday, 12 November, 2013. Gema.

[2] Anees, Ahmad Munawar. 1991. Menghidupkan Kembali Ilmu dalam AlHikmah, Journal of Islamic Studies, JulyOctober, Bandung: Yayasan Mutahhari.

[3] Acikgenc, Alparslan. 2003.Holistic Approach to Scientific Traditions, Islam \& Science: Journal of Islamic Perspective on Science, Volume 1, June 2003.

[4] Bakar, Osman. 2003.Reformulating a Comprehensive Relationship Between Religional and Science: An Islamic 
Perspective, Islam \& Science: Journal of Islamic Perspective on Science, Volume 1, Number 1, June 2003.

[5] Wan Ramli bin Wan Daud dan Shaharir bin Mohamad Zain. 1999. Pemelayuan, Pemalaysiaan dan Pengislaman Ilmu Sains dan Teknologi dalam Konteks Dasar Sains Negara, Journal Kesturi, No. 1.

[6] Thoyyar, Huzni.Model-Model Integrasi Ilmu Dan Upaya Membangun Landasan Keilmuan Islam. Survey Literatur Terhadap Pemikiran Islam Kontemporer. Paper. Unpublished.

[7] Stenberg, Leif. 1997.The Islamization of Science: Four Muslim Positions Developing an Islamic Modernity. Journal of Islamic Studies, Vol. 36, No. 3, 1997.

[8] Fikrah, Azizah Herawati. 2015. Ulul Albab's Contextual concept in present era.Azizah_hera@yahoo.co.id.

[9] Rofa, Mat.2018. Collaboration between International Institute of Islamic Thought (IIIT) and International Program for Islamic Economics and Finance (IPIEF), Faculty of Economics and Business, Universitas Muhammadiyah Yogyakarta.

[10] Denzin, N. K. and Y.S. Lincoln, 1994. Hanbook of Qualitative Research. Thousand Oaks, California: SAGE Publications, Inc.

[11] Bogdan, R.C. and S.K. Biklen. 1982.Qualitative Research Education: an Introduction to Theory and Method, London, Allin \& Bacon, Inc.

[12] Lind, Fabienne. et al. 2019. When the Journey Is as Important as the Goal: A Roadmap to Multilingual Dictionary Construction. International Journal of Communication. Vol. 13 (2019), pp. 4000-4020. http://ijoc.org.

[13] Tharaba, Muhammad Fahim. 2014.Manajemen Pendidikan Berbasis Ulū al-Albāb Dalam Konteks Pengembangan Integrasi Ilmu (StudiKasus di Universitas Islam Negeri (UIN)Maulana Malik Ibrahim Malang). Dissertation. Doctorate Program in Islamic Education Management. Post Graduate Program. Universitas Islam Negeri Maulana Malik Ibrahim Malang, Indonesia.
[14] Nasr, Sayyed Hossein. 1970.Science and Civilization in Islam, New York: New American Library.

[15] Hassan Asilian-Mahabadia, et al. 2018. A qualitative investigation of factors influencing unsafe work behaviors on construction projects. IOS Press. Work 61 pp. 281-293. DOI:10.3233/WOR-182799.

[16] Clary, Renee, and James Wandersee. 2010. Fishbone Diagram: Organize reading content with a "Bare Bones" strategy. Science Scope, pp 31-37.

[17] Jung Tsun Liu. 2016. The study of Total Quality Management and Job Satisfaction In Land Authority from North Taiwan. The International Journal of Organizational Innovation. Vol. 8, No. 4, pp. 43-63. April 2016

[18] Khozin. 2020. Philosophy framework and science development stepsin PTKI (State Islamic University of Maulana Malik Ibrahim (UIN) Malang), presented on Focus Group Discussion in Rektorat Building, UIN Malang, on 16 March.2020.

[19] Nafis, Muhammad Cholil.Meretas Dikotomi antara Ilmu Agama dengan Ilmu Umum. Paper unpublished..

[20] Raharjo, Mudjia. 2002. Islamisasi Ilmu Pengetahuan Sosiologi Islam Sebagai Sebuah Tawaran. Malang: Cendikia Paramulya.

[21] Turmudi, dkk, 2006 Islam, Sains dan Teknologi Menggagas Bangunan Keilmuan Fakultas Sains dan Teknologi Islami Masa Depan, Malang: UIN Maliki Press.

[22] Natsir, Nanat Fatah.Implementasi Paradigma Wahyu Memandu Ilmu Pada Pembidangan Ilmu-Ilmu Keislaman, Paper, presentedin Workshop of Sciences Consortium.

[23] Abdurrahman bin Abdul Aziz as Sudais. 2017. Lathoiful Hisan fi Tadabburil Qur'an. Riyad. Darul Ma'tsur. 1438 H. 